Received Date : 09-Mar-2015

Revised Date : 31-Oct-2015

Accepted Date : 27-Nov-2015

Article type : Original Article \title{
rainbow trout (Oncorhynchus mykiss) \\ Can heat-killed Gordonia bronchialis enhance growth and immunity in
}

Najmeh Sheikhazdeh ${ }^{1, *}$, Keyvan Tahapour ${ }^{1}$, Katayoon Nofouzi ${ }^{2, *}$, Amir Tukmechi ${ }^{3}$, Sadigheh $^{2}$ Shabanzadeh $^{4}$, Ali Khani Oushani ${ }^{5}$, John Stanford ${ }^{6}$, Graham McIntyre ${ }^{6}$, Karim Mardani ${ }^{7}$

${ }^{1}$ Department of Food Hygiene and Aquatic Animals, Faculty of Veterinary Medicine, University of Tabriz, Tabriz, Iran; ${ }^{2}$ Department of Pathobiology, Faculty of Veterinary Medicine, University of Tabriz, Tabriz, Iran; ${ }^{3}$ Department of Pathobiology and Quality Control, Artemia and Aquatic Animals Research Institute, Urmia University, Iran; ${ }^{4}$ Department of Fisheries, Babol Branch, Islamic Azad University, Babol, Iran; ${ }^{5}$ Department of Fisheries, Science and Research Branch, Islamic Azad University, Tehran, Iran; ${ }^{6}$ BioEos Ltd, Kent, UK. Ex: (Department of Medical Microbiology, Royal Free and University College Medical School, London, UK); ${ }^{7}$ Department of Food Hygiene and Quality Control, Faculty of Veterinary Medicine, Urmia University, Urmia, Iran

Correspondences: N. Sheikhzadeh, Department of Food Hygiene and Aquatic Animals, Faculty of Veterinary Medicine, University of Tabriz, Tabriz, Iran.E-mail: $\underline{\text { sheikh@tabrizu.ac.ir }}$

K. Nofouzi, Department of Pathobiology, Faculty of Veterinary Medicine, University of Tabriz, Tabriz, Iran. E-mail: nofouzi@tabrizu.ac.ir

This is the author manuscript accepted for publication and has undergone full peer review but has not been through the copyediting, typesetting, pagination and proofreading process, which may lead to differences between this version and the Version of Record. Please cite this article as doi: $\underline{10.1111 / a n u .12445}$

This article is protected by copyright. All rights reserved 


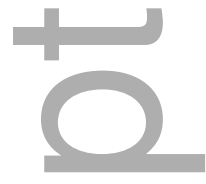

-

29 Abstract

30 In the present study, the efficacy of heat-killed Gordonia bronchialis on growth performance, immune system and gastrointestinal structure in rainbow trout (Oncorhynchus mykiss) were evaluated. Fish (mean weight $30 \mathrm{~g}$ ) were fed basal diet (control), or treatment diets containing $2.48 \times 10^{8}$ (low dose) or $1.24 \times 10^{9}$ (high dose) cells kg ${ }^{-1}$ feed of heat-killed Gordonia bronchialis on a pulse basis (5 days on treatment diet; 10 days on basal diet) for 95 days. On days 95 and 105, some of the fish were sampled for analysis of mentioned parameters. On days 110 and 120, the remaining fish were injected intraperitoneally with a $20 \mathrm{ml} \mathrm{L}^{-1}$ suspension of chicken red blood cells. Results showed that growth performance was significantly enhanced in both treatment groups compared to the control group. Serum complement and lysozyme activities and hemagglutination antibody titer were higher in both treatment groups compared with controls. The length of the intestinal and pyloric caeca folds were increased in the high dose group. Meanwhile, the number of goblet cells was increased in both treatment groups. This study suggests that heat-killed Gordonia bronchialis has the potential to enhance growth, immunological parameters and the gastrointestinal structure in rainbow trout.

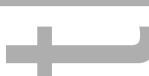

KEY WORDS: Gordonia bronchialis, rainbow trout, immune system, growth, gastrointestinal histology. 


\section{Introduction}

51 It is widely demonstrated that farmed fish are more susceptible to disease agents than their wild 52 counterparts due to the artificial conditions posed by intensive rearing (Price 1999; Huntigford 2004; Salinas et al. 2006). When infectious outbreaks appear they may be fought by means of chemotherapeutics, vaccines or immunostimulants (Salinas et al. 2006). The administration of immunostimulants to fish through the diet has appeared as a very promising control measure in fish farms. In fact, these additives augment the innate and adaptive immune responses and remain the key strategies for prevention of diseases in fish aquaculture. Among the aerobic, near-mycobacterial genera, within the Actinomycetales, are some species with adjuvant activities and antigens very similar to those of Mycobacterium vaccae, but with subtle differences (Stanford \& Stanford 2012). More recently, a number of these species, including Gordonia bronchialis (G. bronchialis), Rhodococcus coprophilus, and Tsukamurella inchonensis, capable of exerting subtly different adjuvant or immunostimulatory activities in human, veterinary and agricultural medicine have been identified (Tarrés et al. 2012). For example, published studies with heat-killed G. bronchialis showed that it could limit parasitaemias in rats challenged with live Trypanosoma cruzi (Fontanella et al. 2007). Pregnant rats treated with $G$. bronchialis also gave birth to offspring protected from subsequent challenge

Some studies have so far addressed the effects of heat-killed G. bronchialis in aquaculture. Oral administration of $G$. bronchialis improved survival and weight gain in shrimp and young fish and enhanced growth rate and color and reduced skeletal abnormalities in koi carp (Cyprinus carpio) (Stanford \& Stanford 2012). In this study, the effects of dietary heat-killed $G$. juvenile rainbow trout (Oncorhynchus mykiss) were evaluated. 
81

82

83

84

85

86

87

88

89

90

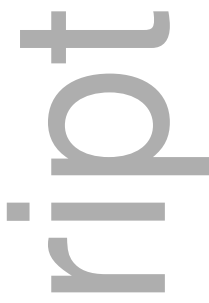

84

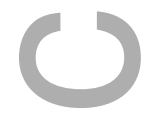

91 Materials and methods

92 Fish

93 The experiment was carried out at a fish farm in Firoozkooh, Iran. Rainbow trout, of 30g average 94 wet weight, were acclimatized for 10 days on the basal diet produced in a commercial mill 95 (Faradaneh, Isfahan, Iran). The open formula of this commercial diet is given in Table 1. Fish 96 were kept in indoor cement tanks $(1.8 \times 0.22 \times 0.35 \mathrm{~m})$ in flow-through system supplied with 97 aerated well water with following characteristics: flow rate $0.51 \mathrm{~s}^{-1}$, water temperature $12 \pm 1^{\circ} \mathrm{C}$, 98 dissolved oxygen $>8 \mathrm{ppm}, \mathrm{NH}_{3}<0.01 \mathrm{mg} \mathrm{l}^{-1}, \mathrm{NO}_{2}<0.1 \mathrm{mg} \mathrm{l}^{-1}$, hardness $275 \mathrm{mg} \mathrm{l}^{-1}$ and $\mathrm{pH} 7.8$. A 99 total of 162 fish were randomly distributed into three experimental groups following a 100 completely randomized design. 
Cultured and heat-killed G. bronchialis by autoclaving was obtained from BioEos Ltd (Kent, UK). Experimental diets were prepared by adding $2.48 \times 10^{8}$ and $1.24 \times 10^{9}$ cells kg${ }^{-1}$ feed of heat-killed G. Bronchialis into commercial basal diet which was equivalent to $2.074 \mathrm{~g}$ and $10.370 \mathrm{~g}$ powder in potato starch, according to the manufacturer. The heat-killed organism was added to the diet by spraying $20 \mathrm{ml}$ fish oil $\mathrm{kg}^{-1}$ feed. A control diet was prepared by spraying 20 $\mathrm{ml}$ fish oil $\mathrm{kg}^{-1}$ only to the basal diet. The modified feed was stored in tightly sealed plastic bags at $8-10^{\circ} \mathrm{C}$ until they were used in the feeding experiments. Three groups in triplicate with 18 fish in each tank were fed the experimental diets formulated with $2.48 \times 10^{8}$ or $1.24 \times 10^{9}$ cells of dead G. bronchialis, or the basal diet for 95 days with pulse administration of treatment diet for 5 days followed by 10 days on the basal diet as following: day 1 till 5: treatment diet; day 6 till 15: basal diet; day 16 till 20: treatment diet; day 21 till 30: basal diet. Similar pattern was followed till day 95 . From day 95 till day 105, fish were reverted back to the basal diet. Fish were sampled on days 95 and 105 to evaluate whether the effects of using this immunostimulant would last till that time. In this study, fish were initially fed at a feeding rate of $25 \mathrm{~g} \mathrm{~kg}^{-1}$ of body weight daily; this rate was designed to assure apparent satiation. Till the end of the trial, fish were weighed once every 2 weeks to adjust the feeding during the experiment.

\section{Growth performance}

All fish in each tank were taken and weighed at the beginning and the termination of the feeding trial on day 95. Feed conversion ratio (FCR) and thermal growth coefficient (TGC) were determined for each tank using the following formula:

FCR $=$ total feed supplied / weight gain

$\mathrm{TGC}=\left[\mathrm{W} 2^{1 / 3}-\mathrm{W} 1^{1 / 3} /\left(\mathrm{T} 2-\mathrm{T}_{1}\right) \times{ }^{\circ} \mathrm{C}\right] \times 1000$, where $\mathrm{W}_{1}$ and $\mathrm{W}_{2}$ are the initial and final weight $(\mathrm{g})$, respectively, $\mathrm{T} 2-\mathrm{T} 1$ is the number of days in the feeding period and ${ }^{\circ} \mathrm{C}$ is the mean daily temperature (Sanden et al. 2006).

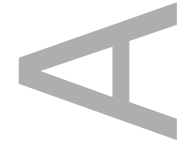

\section{Immunological parameters}


On days 95 and 105 of the trial, four fish from each tank were anaesthetized in a clove oil bath $\left(50 \mu \mathrm{L}^{-1}\right)$ and blood was collected from the caudal vein. Fish bloods were allowed to clot at room temperature for $1 \mathrm{~h}$ and stored in a refrigerator overnight. The clot was then centrifuged at $1500 \mathrm{~g}$ for $5 \mathrm{~min}$. Then the serum was collected and stored in sterile eppendorf tubes at $-20^{\circ} \mathrm{C}$ until used for assays. Noteworthy, all sampling fish for immunological parameters were removed from study after blood collection.

Serum lysozyme activity was measured according to methods described by Demers \& Bayne (1997). Briefly, $25 \mu \mathrm{l}$ of individual serum samples was mixed with a $175 \mu 1$ Micrococcus lysodiekticus (Sigma) suspension at $75 \mathrm{gg} \mathrm{ml}^{-1}$ in $0.1 \mathrm{M}$ phosphate citrate buffer, pH 5.8. After rapid mixing, turbidity changes were measured every $30 \mathrm{~s}$ for $5 \mathrm{~min}$ at $450 \mathrm{~nm}$ at approximately $20^{\circ} \mathrm{C}$ using a microplate reader. The dilutions of hen eggwhite lysozyme (Sigma) ranging from 0 to $20 \mu \mathrm{g} \mathrm{ml}^{-1}$ in the same buffer served as the standard. The equivalent unit of activity of the sample as compared to the standard was determined and expressed as $\mu \mathrm{g} \mathrm{ml}^{-1}$ serum.

Alternative complement serum activity was determined using previously reported method (Andani et al. 2012). Rabbit red blood cells (RaRBC) were washed three times in ethylene glycol tetra acetic acid-magnesium-gelatin veronal buffer (0.01 M EGTA-Mg-GVB, pH 7) and

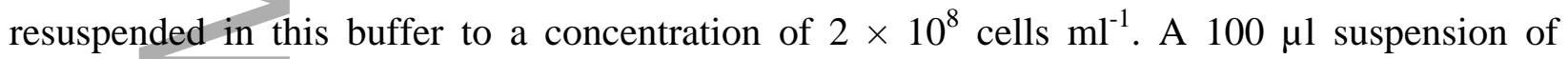
$\mathrm{RaRBC}$ was added to $250 \mu \mathrm{l}$ of serially diluted serum in buffer. Samples were incubated at $20^{\circ} \mathrm{C}$ for $90 \mathrm{~min}$ with regular shaking. Approximately $3.15 \mathrm{ml}$ of $0.85 \% \mathrm{NaCl}$ solution was added and the tubes centrifuged at $1600 \mathrm{~g}$ for $10 \mathrm{~min}$ at $4{ }^{\circ} \mathrm{C}$. The extent of hemolysis was estimated by measuring the optical density of the supernatant at $414 \mathrm{~nm}$ using a spectrophotometer (Awarness, Palm, FA). ACH50 units were defined as the concentration of serum giving $50 \%$ hemolysis of RaRBC.

Total antibody level in the serum was determined following the method of Siwicki et al. (1994). The difference in total protein content prior to and after precipitation of the antibody component with $12 \%$ polyethylene glycol (PEG; Sigma) was determined by the Bradford method (Kruger 1996).

The total peroxidase content present in serum was measured according to Cuesta et al. (2005). Serum samples $(15 \mu \mathrm{l})$ were placed in each well of a 96 well plate. $135 \mu \mathrm{l}$ of HBSS without 
$\mathrm{Ca}+2$ or $\mathrm{Mg}+2$ was then added to each well. Finally $50 \mu \mathrm{l}$ of $20 \mathrm{mM} 3,30,5,50-$ tetramethylbenzidine hydrochloride (TMB) (Sigma) and 5 mM H2O2 was added. The colorchange reaction was stopped after $2 \mathrm{~min}$ by adding $50 \mu \mathrm{l}$ of $2 \mathrm{M}$ sulfuric acid and the optical density was read at $450 \mathrm{~nm}$ by ELISA reader.

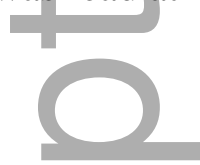

\section{Gastrointestinal histological parameters}

Tissues were collected from two fish in each tank on days 95 and 105 of the trial. Noteworthy, sampling fish for histology were in addition to the fish used for immunological parameters. After necropsy, macroscopic observations were performed. Then, liver, kidney, spleen, gills, skeletal muscle, intestine, pyloric caeca samples were taken, separately. Samples were fixed in buffered formalin for $48 \mathrm{~h}$, dehydrated in alcohols and xylene and then embedded in paraffin. A five micron subsample was then rehydrated in alcohol and stained with haematoxylin-eosin. Length and thickness of proximal intestinal and pyloric caeca folds were measured using a graded ocular lens. The percentage of goblet cells among all epithelial cells in fish proximal intestine and pyloric caeca were also defined. Goblet cell percentage was determined by counting 20 folds in each fish and about five sections per sample. The magnification used was $\times 200$.

\section{Challenge test with chicken red blood cells $(C-R B C)$ suspension}

Red blood cells were collected from 28 days old, Ross strain broiler chickens raised under recommended rearing requirements (Ross Broiler Management handbook, Aviagen, 2014). Two milliliters of citrated (3.8\% NaCit solution at 1:10 dilution) chicken blood was suspended in 10 $\mathrm{ml}$ Tris buffered saline (TBS, $50 \mathrm{mM}$ Trise $\mathrm{HCl}, \mathrm{pH} 8.0,150 \mathrm{mM} \mathrm{NaCl}$ ) and centrifuged at 2500 $\mathrm{g}$ for $10 \mathrm{~min}$. The supernatant was aspirated without disturbing the blood cells. $10 \mathrm{ml}$ TBS was added and mixed by inverting. Following the centrifugation and washing two more times, the supernatant was aspirated and $2.5 \%$ chicken red blood cell (C-RBC) suspension in TBS was prepared (Sheikhzadeh et al. 2012). On day 110 of trial, all remaining fish in each tank (six fish per tank) were anesthetized in a clove oil bath $\left(50 \mu \mathrm{L}^{-1}\right)$ and injected intraperitoneally with 0.5 $\mathrm{mL}$ of the C-RBC suspension in PBS. 10 days later, these fish received boosting injection. On day 135 of trial, 15 days after boosting injection, blood was collected from these injected fish 
188 and serum was obtained with the same procedure described above and kept for further use at $18920^{\circ} \mathrm{C}$.

\section{Hemagglutination assay}

192 The antigen-specific antibody response was determined by hemagglutination assay (Rao \& 193 Chakrabarti 2005). Blood from chicken was collected in citrate solution and the cells were 194 washed in PBS and resuspended to $20 \mathrm{ml} \mathrm{L}^{-1}$ in PBS. Serum of control or test fish $(50 \mu \mathrm{L})$ was 195 serially diluted in PBS in 96 well round-bottomed microtiter plates. An equal volume of $20 \mathrm{ml} \mathrm{L}$ $196{ }^{1} \mathrm{C}-\mathrm{RBC}$ was added to all wells and kept for $1 \mathrm{~h}$ at room temperature and then overnight at $4^{\circ} \mathrm{C}$. 197 Hemagglutinating antibody titer was expressed as the reciprocal of the highest dilution giving 198 visible agglutination.

199

200 Statistical analysis

201 The results were expressed as a mean \pm standard error (SEM). The statistical significance of data 202 was evaluated by two-way and one-way analysis of variance (ANOVA), using the statistical 203 package for social sciences (SPSS) software version 19.0. The data were analyzed by LSD 204 analysis with the least square difference to compare the means. Differences were considered 205 significant at $P<0.05$.

206

207

208

209

210

211

212

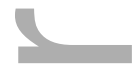

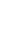
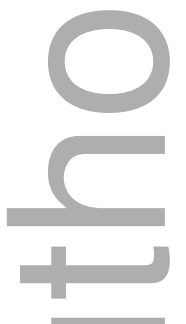


\section{Results}

219 Growth performance

220 Final weight, final length, FCR, and TGC improved significantly in both treatment groups 221 compared to the control group (Table 2).

224 No significant differences in all immunological responses between day 95 and 105 were shown 225 during this trial. Dietary intake of heat-killed G. bronchialis in both treatment groups increased the serum complement activity compared to the control group on days 95 of the feeding trial.

227 Similar increase was also shown on day 105 of the trial. No significant impact on serum total 228 antibody and peroxidase contents in any treatment group was noted on days 95 and 105 of the 229 study. In the assay of lysozyme activity in serum of fish treated with both low and high dose of G. bronchialis, significant elevation was observed compared with the control group on days 95 231 and 105 of the study (Table 3). After immunization, the antigen-specific response was significantly higher in the high dose groups than the control group on day 130 of trial whereas no significant differences were noticed between treatment groups (Figure 1).

Histological findings

Upon post-mortem examination, no gross lesions or microscopic changes were detected in any group. No pathological changes were also noted in the intestine and pyloric caeca of fish from all groups that shows the normal architectures of these tissues. In fish that received the high dose of heat-killed G. bronchialis, the intestinal fold length increased compared to low dose group and control group on days 95 and 105 of feeding. No significant change in fold thickness in any 241 group was shown on day 95 of trial where as on day 105 fold thickness increased in both 242 treatment groups in comparison with control group. Significant increase in mucous cell numbers 243 for fish in both treatment groups were shown compared to the control group on day 95 of the 
trial. Highest elevation was just noted in fish receiving the high dose of heat-killed $G$. bronchialis. Meanwhile, on day 105 of the study, mucous cell numbers was only increased in fish received the high dose G. bronchialis compared with other groups. Comparing the intestinal morphology on days 95 and 105, significant differences in goblet cells number were only noted between control fish (Table 4).

On days 95 and 105 of the trial, the fold length of the pyloric caeca increased in fish fed the high dose of heat-killed G. bronchialis compared with control and low dose group. On day 95, higher fold thickness of the pyloric caeca was observed in both treatment groups compared to the control group. Whereas on day 105 fold thicknesses did not change in any treatment group compared with the control group. Higher numbers of mucous cells in pyloric caeca were exhibited in both treatment groups compared with the control group on days 95 and 105 of trial. Additionally, highest mucous cell number was just noted in fish fed the high dose of heat-killed G. bronchialis. Comparing the pyloric caeca morphology on days 95 and 105, similar pattern to intestine were shown in a way that significant differences in goblet cells number between control fish were noted (Table 5).
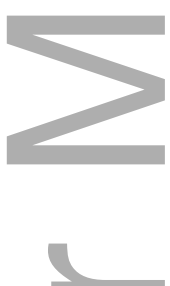

\section{Discussion}

\section{Discussion}

The results show that heat-killed G. bronchialis in both treatment groups enhanced the growth performance in rainbow trout. Similar results were observed in koi carp and shrimp (Stanford \& Stanford 2012). In fish species, higher growth performance can happen by different mechanisms (Heidarieh et al. 2012). Influencing nutrient especially protein digestibility by maintaining the function and structure of the small intestine leads to increased digestive capacity of the gut. Improved digestive enzymes, including lipase, amylase and protease could also result in better growth performance. In the present study, histological examination showed some differences in small intestine and pyloric caeca structures. In the high dose group, increased fold length in the intestine and pyloric caeca were noted. Thicker folds in the pyloric caeca and intestine in both 
treatment groups were also shown on days 95 and 105 of the feeding trial, respectively. Numerous anatomical features determine the total absorptive surface area of the gastrointestinal tract. For example, taller, narrower and regularly shaped fold and higher number of fold per unit area are indicators that the function of the intestinal folds is activated (Heidarieh et al. 2013). In this study, taller shaped fold in the high dose group were a good indicator but the thicker folds should be evaluated further to elucidate the effects, which will happen to fish administrated with heat-killed G. bronchialis. Comparing the effects of intestinal morphology with growth performance, it is clear that most intestinal changes were exhibited with a higher dose of administration. However, similar growth performance in both treatment groups was observed compared to the control group. Therefore, other factors may also have affected the growth performance in this study. Noteworthy, this trial was carried out on commercial fish farm; different additives inside the extruded diet might also interact with heat-killed G. bronchialis. Therefore, to elucidate the exact mechanisms through which the heat-killed G. bronchialis can affect the growth in fish, administration of this heat-killed bacterium in a diet without any additives is needed.

In this study, large amount of goblet cells in fish gastro-intestine after feeding dead $G$. bronchialis were noted. Even though higher goblet cell density in fish skin and intestinal tract after challenge with infectious diseases have been widely studied (Buchmann \& Bresciani 1998; Ring $\varnothing$ et al. 2003) increase in mucus production in response to the feed additives were also shown (Torresillas et al. 2011; Covello et al. 2012; Heidarieh et al. 2012; Xueqin et al. 2012; Shin et al. 2014). Goblet cells in the gastrointestinal tract provide protection against damage by forming a viscous, hydrated blanket on the surface of the mucosa which acts as a sensitive first line ef immune defense parameter in fish (Shin et al. 2014). Meanwhile, it was suggested that goblet cells positively affect the absorption of digestible substances (Shin et al. 2014) that can partly explain the improvement in growth performance in fish administrated with heat-killed $G$. bronchialis.

Heat-killed G. bronchialis in both treatment groups were effective in enhancing serum lysozyme and complement activities. On other hand, total antibody and peroxidase levels were not affected by administration of dead G. bronchialis. The lysozyme and alternative pathway of complement are powerful non-specific defense mechanisms for protecting fish against a wide range of 
potentially invasive organisms, such as bacteria, fungi, viruses, and parasites (Choi et al. 2008; Son et al. 2009). In fact, the innate immune system of fish comprises several humoral and cellular factors that may differentially respond to the offered immunostimulants (Shin et al. 2014). After immunization, higher antigen-specific response was shown in high dose group, showing the positive effect of heat-killed $G$. bronchialis on specific immune responses in rainbow trout. Immunostimulatory effects of dead G. bronchialis have been earlier reported in laboratory animal and veterinary medicine (Fontanella et al. 2007; Davila et al. 2011; Marro et al. 2011; Stanford \& Stanford 2012; Smaldini et al. 2013). The effectiveness of preparations of heat-killed Actinomycetales is attributed to highly active immunostimulatory adjuvants in their cell walls, with subtle differences between species (Marro et al. 2011).

Considering the long period of fish culture, continual feeding of immunostimulants might have harmful effects on the immune system (Bricknell \& Dalmo 2005). Therefore, a pulse feeding strategy during 95 days, with treatment diet for 5 days followed by basal diet for 10 days, was evaluated. Results showed up-regulation of the immune system after administration of heatkilled G. bronchialis on day 95 of trial. Meanwhile, fish were also sampled on day 105 to analyze the effects of 10 days withdrawal time on different immunological and histological parameters. In fact, on day 105 an enhanced response of the immune system and histological parameters fairly similar to day 95 were noted even though goblet cell percentage in low dose group returned to baseline which shows the minor decrease in immune stimulation. Noteworthy, comparing the immunological and histological parameters on days 95 and 105, significant differences in goblet cells number in intestine and pyloric caecum between control fish were noted whereas no significant differences in treatment groups between day 95 and 105 were shown during this trial. The exact reason for differences in goblet cells number between control fish is unknown and needs more considerations to clarify these observations. Converse to this substance, immune stimulation by feeding a probiotic is more transient and a few days after cessation of probiotic administration, it decreases dramatically (Andani et al. 2012). Reduction in immune responses following the administration of probiotics can be attributed to a decrease in bacterial count after feeding on the basal diet (Andani et al. 2012). In general, immune stimulation by feeding different substances even in withdrawal time can provide an immense flexibility in fish farming especially during periods of increased disease risk. 
333 In conclusion, this preliminary study showed that administration of heat-killed G. bronchialis has 334 beneficial effects in rainbow trout, affecting parameters like growth performance, immunity and 335 gastrointestinal structure. Further investigations are needed to fully understand the interaction 336 between this organism and different fish species even on the molecular level.

\section{Acknowledgements}

341 The authors wish to express their gratitude to BioEos Ltd. for supplying heat-killed $G$. 342 bronchialis. The authors are also grateful to Research affairs of Tabriz University for the 343 financial support.

\section{References} [1] Andani, H.R.R., Tukmechi, A., Meshkini, S. \& Sheikhzadeh, N. (2012) Antagonistic activity of two potential probiotic bacteria from fish intestines and investigation of their effects on growth performance and immune response in rainbow trout (Oncorhynchus mykiss). J. Appl. Ichthyol., 28, 728-734.

[2] Bricknell, I. \& Dalmo, R.A. (2005) The use of immunostimulants in fish larval aquaculture. Fish Shellfish Immunol., 19, 457-472. 
[3] Buchmann, K. \& Bresciani, J. (1998) Microenvironment of Gyrodactylus derjavini on rainbow trout Oncorhynchus mykiss: association between mucous cell density in skin and site selection. Parasitol. Res., 84, 17-24.

[4] Choi, S.H., Park, K.H., Yoon, T.J., Kim, J.B., Jang, Y.S. \& Choe, C.H. (2008) Dietary Korean mistletoe enhances cellular non-specific immune responses and survival of Japanese eel (Anguilla japonica). Fish Shellfish Immunol., 24, 67-73.

[5] Covello, J.M., Friend, S.E., Purcell, S.L., Burka, J.F., Markham, R.J.F., Donkin, A.W., Groman, D.B. \& Fast, M.D. (2012) Effects of orally administered immunostimulants on inflammatory gene expression and sea lice (Lepeophtheirus salmonis) burdens on Atlantic salmon (Salmo salar). Fish Shellfish Immunol.,366-367, 9-16.

[6] Cuesta, A., Rodriguez, A., Esteban, M.A. \& Meseguer, J. (2005) In vivo effects of propolis, a honeybee product, on gilthead seabream innate immune responses. Fish Shellfish Immunol., 18, 71-80.

[7] Davila, H., Didoli, G., Bottasso, O. \& Stanford, J. (2011) Maternal immunization with Actinomycetales immunomodulators reduces parasitaemias in offspring challenged with Trypanosoma cruzi. Immunotherapy, 3, 577-583.

[8] Demers, N.E. \& Bayne, C.J. (1997) The immediate effects of stress on hormones and plasma lysozyme in rainbow trout. Develop. Comp. Immunol., 21, 363-373.

[9] Fontanella, G.H., Pascutti, M.F., Daurelio, L., Perez, A.R., Nocito, A.L., Wojdyla, D., Bottasso, O., Revelli, S.S. \& Stanford J.L. (2007) Improved outcome of Trypanosoma cruzi infection in rats following treatment in early life with suspensions of heat-killed environmental Actinomycetales. Vaccine, 25, 3492-3500.

[10] Heidarieh, M., Mirvaghefi, A.R., Akbari, M., Farahmand, H., Sheikhzadeh, N., Shahbazfar, A.A. \& Behgar, M. (2012) Effect of dietary Ergosan on growth performance, digestive enzymes, intestinal histology, hematological parameters and body composition of rainbow trout (Oncorhynchus mykiss). Fish Physiol. Biochem., 38, 1169-1174. 
[11] Heidarieh, M., Mirvaghefi, A.R., Sepahi, A., Sheikhzadeh, N., Shahbazfar, A.A. \& Akbari, M. (2013) Effects of dietary Aloe vera on growth performance, skin and gastrointestine morphology in rainbow trout (Oncorhynchus mykiss). Turk. J. Fish Aquat. Sci., 13, 367-373.

[12] Huntigford, F.A. (2004) Implications of domestication and rearing conditions for the behaviour of cultivated fishes. J. Fish. Biol., 65, 122.142.

[13] Kruger, N.J. (1996) The Bradford method for protein quantitation. In: The protein protocols handbook. (Walker, J.M. ed), pp. 11-15.Humana Press, Totowa, NJ, USA.

[14] Marro, A., Pirles, M., Schiaffino, L., Bin, L., Davila, H., Bottasso, O.A., McIntyre, G., Ripley, P.R., Stanford, C.A. \& Stanford, J.L. (2011) Successful immunotherapy of canine flea allergy with injected Actinomycetales preparations. Immunotherapy, 3, 971-978.

[15] Nootash, S., Sheikhzadeh, N., Baradaran, B., Khani Oushani, A., Maleki Moghadam, M.R., Nofouzi, K., Monfaredan, A., Aghebati, L., Zare, F. \& Shabanzadeh, S. (2013) Green tea (Camellia sinensis) administration induces expression of immune relevant genes and biochemical parameters in rainbow trout (Oncorhynchus mykiss). Fish Shellfish Immunol., 35, 1916-1923.

[16] Price, E.O. (1999) Behavioral development in animals undergoing domestication. Appl. Anim. Behav. Sci., 65, 245-271.

[17] Rao, V. \& Chakrabarti, R. (2005) Stimulation of immunity in Indian major carp Catla catla with herbal feed ingredients. Fish Shellfish Immunol., 18, 327-334.

[18] Ring $\varnothing$, E., Olsen, R.E., Mayhew, T.M. \& Myklebust, R. (2003) Electron microscopy of the intestinal microflora of fish. Aquaculture, 227, 395-415.

[19] Ross broiler management handbook. Aviagen, UK 2014. Page 1-130. http://en.aviagen.com/assets/Tech_Center/Ross_Broiler/Ross-Broiler-Handbook-2014iEN.pdf 
[20] Salinas, I., Rosales, P.D., Cuesta, A., Meseguer, J., Chabrillón, M., Moriñigo, M.A. \& Esteban, M.A. (2006) Effect of heat-inactivated fish and non-fish derived probiotics on the innate immune parameters of a teleost fish (Sparus aurata L.). Vet. Immunol. Immunopathol., 111, 279-286.

[22] Sheikhzadeh, N., Heidarieh, M., Karimi Pashaki, A., Nofouzi, K., Ahrab Farshbafi, M.

[21] Sanden, M., Krogdahl, A., Bakke-Mckellep, A.M., Buddington, R.K. \& Hemre G.I. (2006) Growth performance and organ development in Atlantic salmon, Salmo salar L. parr fed genetically modified (GM) soybean and maize. Aquacult. Nutr., 12, 1-14.

\& Akbari, M. (2012) Hilyses ${ }^{\mathrm{TM}}$, fermented Saccharomyces cerevisiae, enhances the growth performance and skin non-specific immune parameters in rainbow trout (Oncorhynchus mykiss). Fish Shellfish Immunol., 32, 1083-1087.

[23] Shin, C.H., Cha, J.H., Rahimnejad, S., Jeong, J.B., Yoo, B.W., Lee, B.K., Ahn, H.J., Choi, S.I., Choi, Y.J., Park, Y.H., Kim, J.D. \& Lee, K.J. (2014) Effects of dietary supplementation of Barodon, an anionic alkali mineral complex, on growth performance, feed utilization, innate immunity, goblet cell and digestibility in olive flounder (Paralichthys olivaceus). Asian Australas J. Anim. Sci., 27, 383-390.

[24] Siwicki, A.K., Anderson, D.P. \& Rumsey, G.L. (1994) Dietary intake of immunostimulants by rainbow trout affects non-specific immunity and protection against furunculosis. Vet. Immunol. Immunopathol., 41, 125-139.

[25] Smaldini, P., Stanford, J., Fossati, C.A. \& Docena, G.H. (2013) Modulatory effect of Actinomycetales genera on activation of gut epithelial cells and inhibition of Nuclear FactorkB pathway. Innate Immun., 20, 626-638.

[26] Son, V.M., Chang, C.C., Wu, M.C., Guu, Y.K. \& Chiu, C.H. (2009) Dietary administration of the probiotic, Lactobacillus plantarum, enhanced the growth, innate immune responses, and disease resistance of the grouper Epinephelus coioides. Fish Shellfish Immunol., 26, 691-698.

This article is protected by copyright. All rights reserved 
[27] Stanford, J. \& Stanford, C. (2012) Mycobacteria and their world. Int. J. Mycrobiol., 1, 312.

436

[28] Tarrés, M.C., Gayol, M.D.C., Picena, J.C., Alert, N., Bottasso, O., McIntyre, G., Stanford, C. \& Stanford, J. (2012) Beneficial effects of immunotherapy with extracts derived from Actinomycetales on rats with spontaneous obesity and diabetes. Immunotherapy, 4, 111.

\section{(1)}

[29] Torrecillas, S., Makol, A., Caballero M.J., Montero, D., Gines, R., Sweetman, J. \& Izquierdo, M. (2011) Improved feed utilization, intestinal mucus production and immune parameters in sea bass (Dicentrarchus labrax) fed mannan oligosaccharides (MOS). Aquat. Nutr., 17, 223-233.

[30] Xueqin, J., Kania, P.W. \& Buchmann, K. (2012) Comparative effects of four feed types on white spot disease susceptibility and skin immune parameters in rainbow trout, Oncorhynchus mykiss (Walbaum). J. Fish Dis., 35, 127-135.

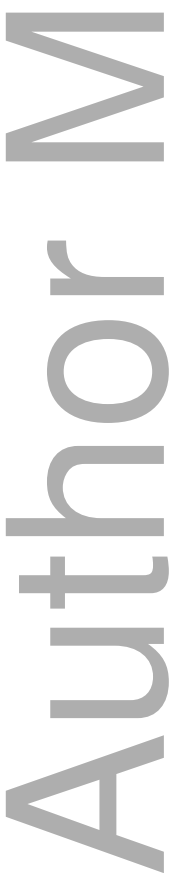


Table 1 Ingredients composition of the commercial basal diet used in this study

\begin{tabular}{|c|c|}
\hline Ingredients $\left(\mathrm{g} \mathrm{kg}^{-1}, \mathrm{DM}\right)$ & Control diet \\
\hline Fish $\mathrm{meal}^{\mathrm{a}}$ & 195 \\
\hline Soybean oil $^{b}$ & 41 \\
\hline Corn flour & 86.5 \\
\hline Soybean meal & 200 \\
\hline Wheat & 173 \\
\hline Poultry byproduct meal & 270 \\
\hline Vitamin mixture $^{\mathrm{c}}$ & 5 \\
\hline Mineral mixture $^{\mathrm{d}}$ & 5 \\
\hline Zeolit & 10 \\
\hline L-Carnithine ${ }^{\mathrm{e}}$ & 0.3 \\
\hline Vitamin $C^{f}$ & 0.2 \\
\hline Molasses & 10 \\
\hline Lysine & 0.6 \\
\hline Methionine & 0.6 \\
\hline Active- $\mathrm{mos}^{\mathrm{g}}$ & 1.5 \\
\hline Natuzyme-p ${ }^{h}$ & 0.3 \\
\hline
\end{tabular}




\begin{tabular}{|c|c|}
\hline $\mathrm{NaCl}$ & 1 \\
\hline $\begin{array}{c}\text { Proximate chemical } \\
\text { analysis }\left(\mathbf{g ~ k g}^{-\mathbf{1}}\right)\end{array}$ \\
\hline Dry matter & 910 \\
\hline Crude protein & 430 \\
\hline Crude lipid & 178 \\
\hline C Ash & 90 \\
\hline Crude fiber & 42 \\
\hline Phosphorus & 14 \\
\hline
\end{tabular}

.$^{a}$ North Sefid Mahi Corporation, Iran with $540 \mathrm{~g} \mathrm{~kg}^{-1}$ crude protein

.${ }^{b}$ North Sefid Mahi Corporation, Iran

${ }^{\mathrm{c}} \mathrm{Unit} \mathrm{kg}^{-1}$ of mixture: Vitamin: retinol acetate (A), $1600000 \mathrm{IU}$; Cholecalciferol (D3), $400000 \mathrm{IU}$; DL- $\alpha$-tocopheryl acetate (E), 40 IU; Menadione sodium bisulfate (K3), 2000 mg; Biotin (H2), 240 mg; Thiamin mononitrate (B1), 6000 mg; Riboflavin (B2), 8000 mg; Calcium d-pantothenate (B3), 12000 mg; Niacinamide (B5), 40000 mg; Pyridoxine hydrochloride (B6), 4000 mg; Folic acid (B9), 2000 mg; Cyanocobalamin (B12), 8000 mg; Vitamin C, 60000 mg; .Inositol, $20000 \mathrm{mg}$; B.H.T., $20000 \mathrm{mg}$; Carrier up to $1 \mathrm{~kg}$

${ }^{\mathrm{d}}$ Unit kg $^{-1}$ of mixture: Mineral: Fe, 26000 mg; Zn, 12500 mg; Se, 2000 mg; Co, 480 mg; Cu, 4200 mg; Mn, 15800 mg; I, 1000 mg; Choline chloride, 12 $.000 \mathrm{mg}$; Carrier up to $1 \mathrm{~kg}$

e Science Laboratories,Iran. Contains: $50 \mathrm{~g} \mathrm{~L}$ Carnithin, Carrier up to $100 \mathrm{~g}$

f Canavit Company, Canada

.${ }^{\mathrm{g}}$ Biorigin Company, Brazil. Conatins: $100 \%$ yeast cell wall 
${ }^{\text {h }}$ T.F.A. Company, Iran. Conatins Unit kg ${ }^{-1}$ of mixture: Cellulase, 6000000 U; Xylanase, 10000000 U; $\beta$-glucanase, 700000 U; $\alpha$-amylase, 700000 U; .Pectinase 70000 U; Phytase, 1500000 U; Lipase, 30000 U; Proteases (Acid \& Neutral), 3000000 U

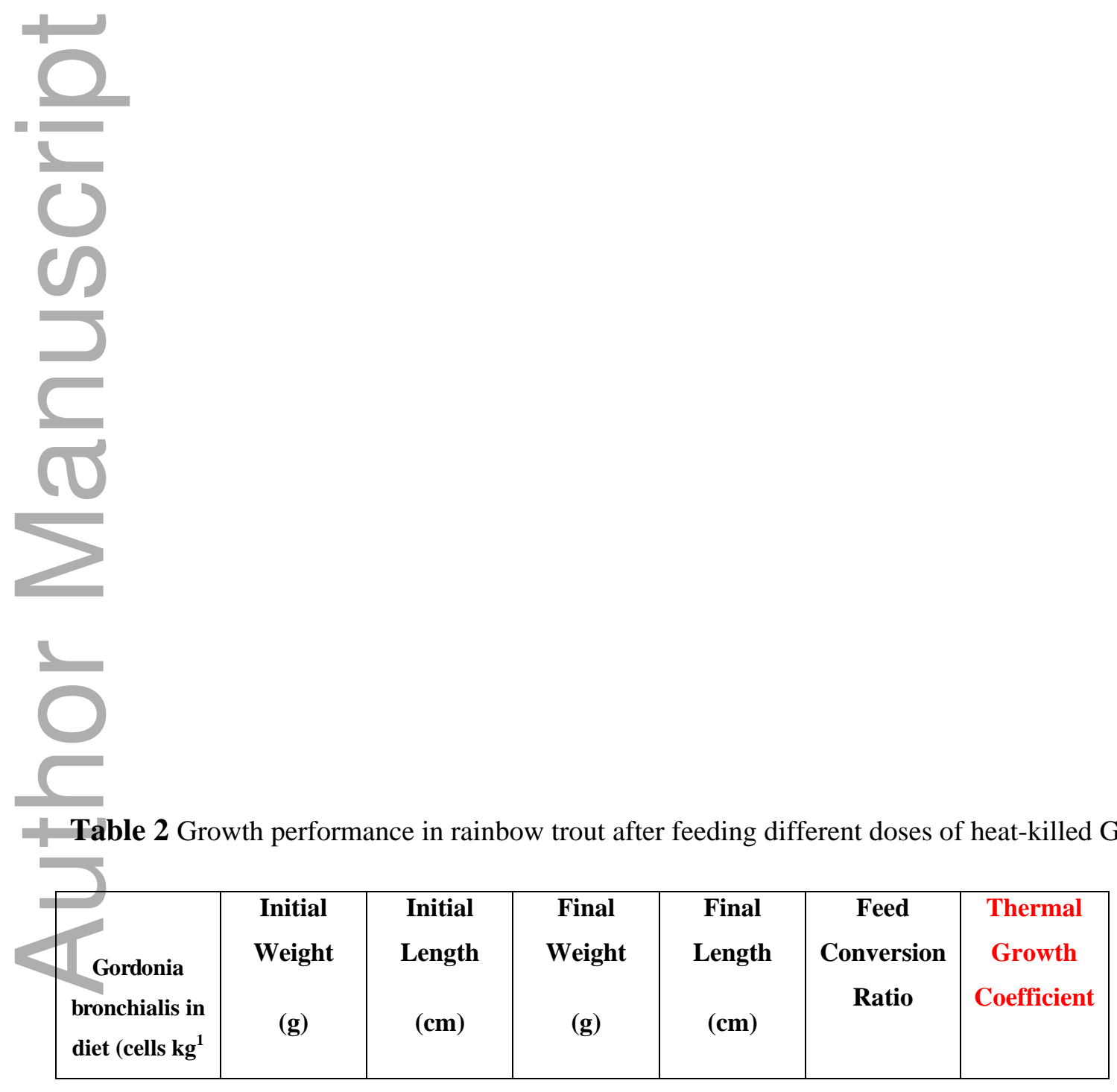

All rights reserved. This article is protected by copyright 


\begin{tabular}{|c|c|c|c|c|c|c|}
\hline feed) & & & & & (FCR) & (TGC) \\
\hline Control & $31.05 \pm$ & $13.99 \pm$ & $135.82 \pm$ & $22.90 \pm$ & $0.91 \pm 0.04^{\mathrm{a}}$ & $1.75 \pm$ \\
& 0.29 & 0.03 & $3.40^{\mathrm{a}}$ & $0.27^{\mathrm{a}}$ & & $0.05^{\mathrm{a}}$ \\
\hline $\mathbf{2 . 4 8} \times \mathbf{1 0}^{\mathbf{8}}$ & $30.98 \pm$ & $13.99 \pm$ & $149.76 \pm$ & $24.08 \pm$ & $0.80 \pm 0.01^{\mathrm{b}}$ & $1.91 \pm$ \\
& 0.23 & 0.03 & $1.62^{\mathrm{b}}$ & $0.23^{\mathrm{b}}$ & & $0.01^{\mathrm{b}}$ \\
\hline $\mathbf{1 . 2 4} \times \mathbf{1 0}^{\mathbf{9}}$ & $30.89 \pm$ & $13.97 \pm$ & $149.83 \pm$ & $24.15 \pm$ & $0.80 \pm 0.01^{\mathrm{b}}$ & $1.90 \pm$ \\
& 0.20 & 0.03 & $2.13^{\mathrm{b}}$ & $0.16^{\mathrm{b}}$ & & $0.01^{\mathrm{b}}$ \\
\hline
\end{tabular}

Data are mean \pm SEM. Those within a column superscripted by $*$ are significantly different $(\mathrm{P}<0.05)$; for FCR and TGC $\mathrm{n}=3$ in each treatment group, for remaining parameters $n=54$ in each treatment group.
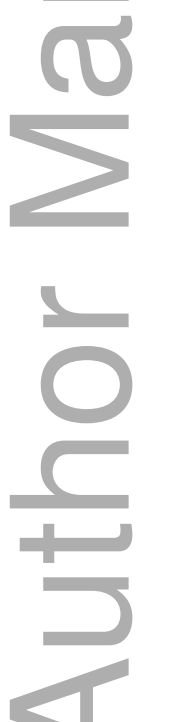

Table 3 Immunological parameters in rainbow trout serum after feeding different doses of heat-killed Gordonia bronchialis 


\begin{tabular}{|c|c|c|c|c|c|c|c|c|c|}
\hline \multirow{5}{*}{$\begin{array}{c}0 \\
10 \\
0 \\
0 \\
0 \\
0 \\
0 \\
0\end{array}$} & $\begin{array}{c}\text { Gordonia } \\
\text { bronchialis }\end{array}$ & \multicolumn{2}{|c|}{$\begin{array}{l}\text { Complement titer } \\
\quad\left(\text { units } \mathbf{m L}^{-1}\right)\end{array}$} & \multicolumn{2}{|c|}{$\begin{array}{l}\text { Total antibody } \\
\qquad\left(\mathbf{m g ~ m L} \mathbf{~}^{-1}\right)\end{array}$} & \multicolumn{2}{|c|}{$\begin{array}{c}\text { Peroxidase } \\
(450 \mathrm{~nm})\end{array}$} & \multicolumn{2}{|c|}{$\begin{array}{l}\text { Lysozyme activity } \\
\left(\mu \mathrm{g} \mathrm{mL} \mathbf{~}^{-1}\right)\end{array}$} \\
\hline & & Day 95 & Day 105 & Day 95 & Day 105 & Day 95 & Day 105 & Day 95 & Day 105 \\
\hline & Control & $0.075 \pm 0.004^{\mathrm{a}}$ & $\begin{array}{r}0.081 \pm \\
0.001^{\mathrm{a}}\end{array}$ & $3.17 \pm 0.20$ & $\begin{array}{r}3.10 \pm \\
0.14\end{array}$ & $\begin{array}{c}0.256 \pm \\
0.002\end{array}$ & $\begin{array}{c}0.249 \pm \\
0.001\end{array}$ & $33.01 \pm 6.77^{\mathrm{a}}$ & $\begin{array}{c}34.89 \pm \\
1.50^{\mathrm{a}}\end{array}$ \\
\hline & $2.48 \times 10^{8}$ & $0.149 \pm 0.009^{b}$ & $\begin{array}{r}0.138 \pm \\
0.007^{\mathrm{b}}\end{array}$ & $3.12 \pm 0.19$ & $\begin{array}{r}2.99 \pm \\
0.23\end{array}$ & $\begin{array}{c}0.262 \pm \\
0.003\end{array}$ & $\begin{array}{c}0.260 \pm \\
0.002\end{array}$ & $\begin{array}{c}112.30 \pm \\
19.55^{\mathrm{b}}\end{array}$ & $\begin{array}{c}115.60 \pm \\
14.51^{\mathrm{b}}\end{array}$ \\
\hline & $1.24 \times 10^{9}$ & $0.141 \pm 0.012^{b}$ & $\begin{array}{r}0.136 \pm \\
0.007^{\mathrm{b}}\end{array}$ & $3.08 \pm 0.20$ & $\begin{array}{r}3.09 \pm \\
0.19\end{array}$ & $\begin{array}{c}0.257 \pm \\
0.002\end{array}$ & $\begin{array}{c}0.254 \pm \\
0.002\end{array}$ & $\begin{array}{c}102.00 \pm \\
8.92^{\mathrm{b}}\end{array}$ & $\begin{array}{c}107.09 \pm \\
8.93^{\mathrm{b}}\end{array}$ \\
\hline
\end{tabular}

Data are mean \pm SEM. Means within a column superscripted by different small letters are significantly different $(\mathrm{P}<0.05)$; Means within a row superscripted by different capital letters are significantly different $(\mathrm{P}<0.05) ; \mathrm{n}=12$ for each treatment group. 
Table 4 Intestinal morphology in rainbow trout after feeding different doses of heat-killed Gordonia bronchialis

Data are mean \pm SEM. Means within a column superscripted by different small letters are significantly different $(\mathrm{P}<0.05)$; Means within a row superscripted by different capital letters are significantly different $(\mathrm{P}<0.05) ; \mathrm{n}=6$ for each treatment group. 


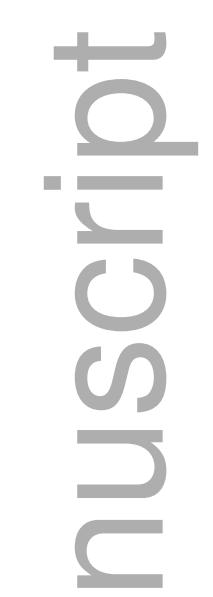

Table 5 Pyloric caeca morphology rainbow trout after feeding different doses of heat-killed Gordonia bronchialis

\begin{tabular}{|c|c|c|c|c|c|}
\hline \multicolumn{2}{|c|}{\begin{tabular}{c|c} 
Gordonia & Fold length $(\mu \mathrm{m})$ \\
bronchialis & \\
in diet & \\
$\left(\right.$ cells $^{-1} \mathrm{~kg}^{-}$ & \\
feed $)$ &
\end{tabular}} & \multicolumn{2}{|c|}{ Fold thickness $(\mu \mathrm{m})$} & \multicolumn{2}{|c|}{ Goblet cell percentage } \\
\hline \begin{tabular}{l|l} 
& Day 95 \\
\end{tabular} & Day 105 & Day 95 & Day 105 & Day 95 & Day 105 \\
\hline \begin{tabular}{l|l} 
Control & $727.50 \pm$ \\
& $21.07^{\mathrm{a}}$
\end{tabular} & $\begin{array}{c}780.83 \pm \\
25.41^{\mathrm{a}}\end{array}$ & $\begin{array}{c}115.10 \pm \\
3.37^{\mathrm{a}}\end{array}$ & $\begin{array}{c}120.83 \pm \\
3.12\end{array}$ & $28.50 \pm 1.24^{\mathrm{aA}}$ & $34.67 \pm 1.63^{\mathrm{ab}}$ \\
\hline \begin{tabular}{c|c}
$\mathbf{2 . 4 8} \times \mathbf{1 0}^{\mathbf{8}}$ & $761.66 \pm$ \\
$17.44^{\mathrm{a}}$
\end{tabular} & $\begin{array}{c}728.50 \pm \\
27.17^{\mathrm{a}}\end{array}$ & $\begin{array}{c}133.33 \pm \\
5.41^{\mathrm{b}}\end{array}$ & $\begin{array}{c}121.66 \pm \\
6.49\end{array}$ & $33.42 \pm 0.82^{\mathrm{b}}$ & $37.92 \pm 1.05^{\mathrm{b}}$ \\
\hline
\end{tabular}

All rights reserved. This article is protected by copyright 


\begin{tabular}{|c|c|c|c|c|c|c|}
\hline $\mathbf{1 . 2 4} \times \mathbf{1 0}^{9}$ & $833.33 \pm$ & $918.33 \pm$ & $141.66 \pm$ & $125.83 \pm$ & $40.50 \pm 1.33^{\mathrm{c}}$ & $41.02 \pm 1.41^{\mathrm{c}}$ \\
& $24.72^{\mathrm{b}}$ & $28.11^{\mathrm{b}}$ & $4.40^{\mathrm{b}}$ & 4.51 & & \\
\hline
\end{tabular}

Data are mean \pm SEM. Means within a column superscripted by different small letters are significantly different $(\mathrm{P}<0.05)$; Means within a row superscripted by different capital letters are significantly different $(\mathrm{P}<0.05) ; \mathrm{n}=6$ for each treatment group.

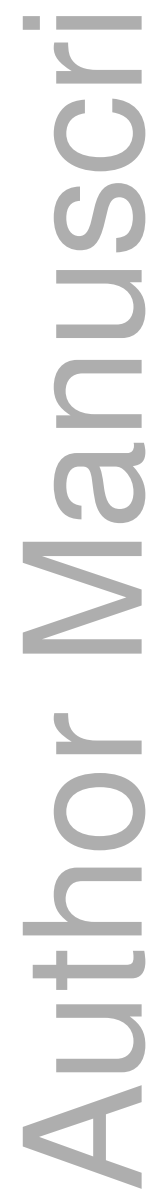




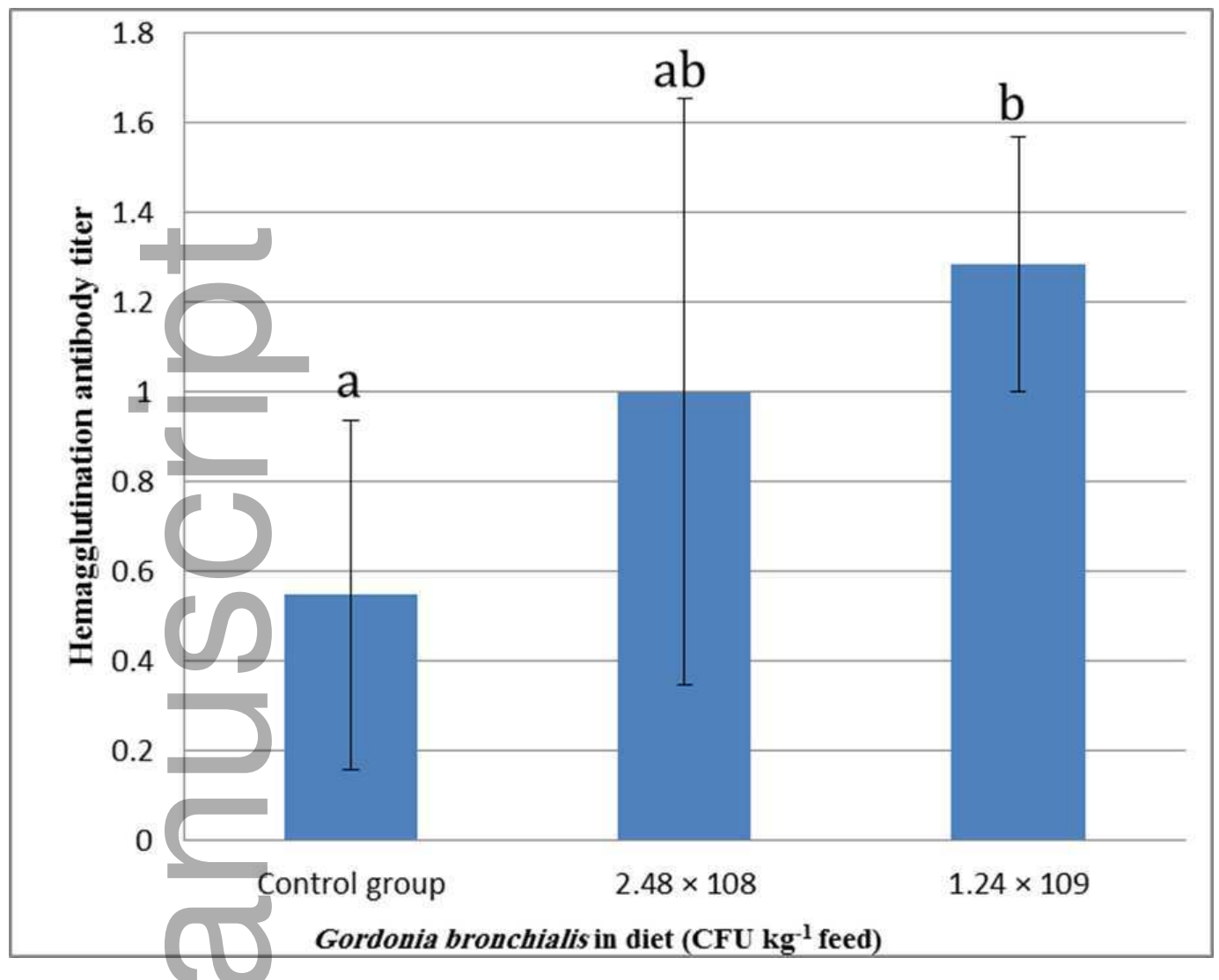

Figure 1 Hemagglutination antibody titer in rainbow trout after feeding different doses of heat-killed Gordonia bronchialis. Data are mean \pm SEM. Those superscripted by different letters are significantly different $(\mathrm{P}<0.05) ; \mathrm{n}=18$ for each treatment group.

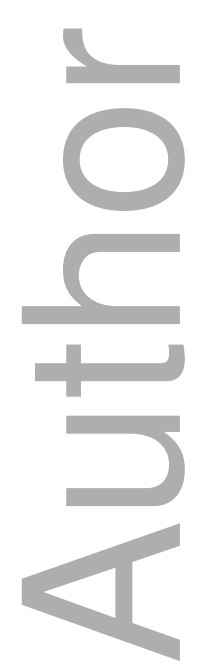




\section{University Library}

\section{- M M N E R VA A gateway to Melbourne's research publications}

Minerva Access is the Institutional Repository of The University of Melbourne

\section{Author/s:}

Sheikhzadeh, N;Tahapour, K;Nofouzi, K;Tukmechi, A;Shabanzadeh, S;Oushani, AK;Stanford, J;McIntyre, G;Mardani, K

Title:

Can heat-killed Gordonia bronchialis enhance growth and immunity in rainbow trout (Oncorhynchus mykiss)?

Date:

2017-08-01

Citation:

Sheikhzadeh, N., Tahapour, K., Nofouzi, K., Tukmechi, A., Shabanzadeh, S., Oushani, A. K., Stanford, J., McIntyre, G. \& Mardani, K. (2017). Can heat-killed Gordonia bronchialis enhance growth and immunity in rainbow trout (Oncorhynchus mykiss)?. AQUACULTURE NUTRITION, 23 (4), pp.788-795. https://doi.org/10.1111/anu.12445.

Persistent Link:

http://hdl.handle.net/11343/291630 